\title{
THE INFLUENCE OF THE ENGLISH LANGUAGE ON THE RUSSIAN YOUTH SLANG
}

Guzel A. Izmaylova ${ }^{1}$

Gulyusa R. Zamaletdinova ${ }^{2}$

Sholpan K. Zharkynbekova ${ }^{3}$

Abstract: This paper deals with the analysis of modern youth slang in the English language. The definition of slang attracts attention of modern philologists. Now there are a fairly large number of slang definitions that quite often contradict each other. Slang is one of the most problematic and main aspects of lexicology, as it reflects the linguistic and cultural features of the society that uses it. Students should select texts based on the language of their future specialty, make assignments for the consolidation of the passed terminology (Erofeeva \& Yusupova, 2018). Today, slang is one of the most interesting language systems of modern linguistics. This paper discusses issues related to such a concept as slang, the problems of its use in spoken language of modern youth, as well as the reasons for the penetration of vocabulary into the language. In the course of studying, analysis method and questionnaires were used. Questionnaires enabled to quickly identify and interview large groups of people by a small number of sociologists. The ways of borrowing from other languages, the main ways of the formation of slang expressions were analyzed, the question of frequent use of these or those words in the spoken language of youth was also considered.

Keywords: dialect, youth slang, slang expressions, stylistic features.

\section{Introduction}

Slang is a variety of spoken language. Speech variety, or linguistic variety, refers to any distinguishable form of speech used by a speaker or a group of speakers. Linguistic features of speech variety can be found at the

\footnotetext{
${ }^{1}$ Kazan Federal University, Tel: +79033132945. Email: guzel.gulyusa@mail.ru.

${ }^{2}$ Kazan Federal University.

${ }^{3}$ L. N. Gumilyov Eurasian National University.
} 
lexical, phonological, morphological or syntactic level of the language. Unlike the emotional component, the evaluative component does not contribute to optionality or diminution of syntactic links (Arnold, 2010).

Over the past few decades, the pace of development of certain areas of public life has repeatedly accelerated in comparison with the previous periods. These processes have caused certain changes in the vocabulary of certain countries, since language is inseparable from culture. All the events that embrace society have a living influence on the development of informal conversation, receive a response in the languages of the world, and add new phrases and expressions to modern vocabulary. Slang is a kind of speech variety. Speech variety, or language variety, refers to any distinguishable form of speech used by a speaker or a group of speakers. Linguistic features of a speech variety can be found at the lexical, the phonological, the morphological, or the syntactical level of the language (Dai \& He, 2002).

In each sector of society, a small number of expressions are used for conversational communication between participants, which are attributes of this contingent of people - vocabulary, slang. It arises in one group of people but at the same time extends within the entire class of society. According to L.A. Kudryavtsev, judging by the definition in the dictionary, professional slangs and professionalisms are considered to be slang (Kudryavtseva \& Prikhodko, 2006).

The study of the origin of words was formerly very popular, and the etymology, the traditional components of a dictionary entry were often discussed, even though, "the amateurs who filled the pages of popular magazines with their own speculations about the origin of words in the late 1900s remained oblivious about the fact that they should have used their time to read, not write".

New borrowed words appeared due to the development of world trade, international tourism, cultural ties. Youth is an integral part of any society, regardless of its inherent features. It is a socio-demographic group, united according to certain signs: age, social status and socio-psychological properties. Youth culture is a particularly complex phenomenon. Youth culture is 
one of the consequences of the process of socialization in general and culture in particular. Its socio-psychological sources lie in the striving of youth as a whole and its specific representatives for knowing, self-affirmation, selfexpression and self-realization. These natural aspirations do not always win the necessary support. Y.V. Gorshunov in his writings notes that "abbreviation is the abridgement made from initial letters of abbreviated words" (Gorshunov, 2012).

The main tendency of the youth subculture almost always lies in the fixation of the worldview concepts of a vivid expressive form most important for them, and perhaps incomprehensible to most people in society. The use of slang in the speech of adolescents gives it flavor and emotionality, in youth's judgement. Teens also use Englishlanguage slang, which is sometimes only understood by youth to express their thoughts.

\section{Methods}

Slang is one of the most interesting and at the same time complex linguistic phenomena. Slang refers to social dialects. Dialect in this context is a territorial, temporary, or social form of a language. In English lexicography, the term "jargon" was widely adopted at about the beginning of the last century in the etymology of the word. Slang is also a complex and inevitable phenomenon of a language. Its emergence is always caused by historical, social and cultural trends. Slang is a play of words, which is the result of communication among young people that occur through the coinage of new words. The willingness of teenagers to implement the idea through modern computer technologies and the ability to independently select and use art materials, techniques and their combinations according to the subject and the design task have noticeably increased ( Mishina et al., 2018).

These comparisons are so original and vivid that they cannot be created without imagination, while the thinking machine (brain), brilliant (diamond), assemblers (hands) are more vivid and expressive. Sometimes slang expressions are transformed by speakers to use the up-to-dateness of the word and at the same time imitate the others that are relevant to modern speech. Many slang words coined during the Second 
World War went out of use along with the events.

Slang is interesting not only from the viewpoint of linguistic theory, but also from the viewpoint of translation theory. Youth slang in Russia encompasses almost all spheres of life. Slang is focused on a person - spheres of his life, relationships with other people.

The contribution of slang to linguistic enrichment, but for the real idea of the dynamism of the language and the symbol of human freedom in creating the language, was an interesting phenomenon for analyzing.

The expression slang means a transition to a democratic atmosphere in the language, since the meaning of being is not absolute. It depends on who speaks it, which group the users belong to and what situation the slang word occurs in. The contribution of slang in enriching language; a short of real representation of the dynamism of language and symbol of human freedom in creating language was an interesting phenomenon to be analyzed (Hoey, 2012). The question of how to use slang in daily communication has arisen. The choice of a certain slang that replaces a standard word can have specific goals.
The Internet, its capabilities, and computer technologies being in rapid evolution enormously draw young people. Today, English slang is instrumental to young people in their everyday communication. Slang has been formed and changed by various cultures and the advent of technologies which are a phenomenon of language development.

Modern musical culture is one of the interests of youth, which is a part of the life of young people. Modern music is a mixture of different cultures, musical trends, the result of composer experiments. Foreign music is more popular among young people, they are sometimes skeptical about Chinese performing musicians and compositions, English is the most promising for learning in youth society, which is familiar to many young people. Another feature of slang is the disappearance of slang expressions. This is due to the fact that the younger generation no longer uses them. Many words appear in the spoken language of young people from computer games. School slang can be qualified as corporate youth slang.

The slang expression means coming to democratic atmosphere in 
language since the meaning embodied is not absolute. It depends upon who uses it, in which group the users belong to, and in what situation slang word occur. The question emerged is how the user of slang employ slang in their daily communication. Their choice of certain slang replacing the standard may have a certain purposes (Jones, 2009).

Today, in the Russian language you can see many examples of borrowed words, the so-called Russianized words, this adaptation occurs as follows: by adding Russian suffixes, abridgements, reproduction of words, declension, etc. This method does not coin new words. But this helps to "tame" them and make them more native: they are easily integrated into the Russian language system with the help of Russian grammar. We also want to highlight the terminology by A.A. Ionin: "abbreviation is a linguistic phenomenon, which should reflect both the general features and laws of languages, as well as the internal features inherent in individual languages" (Ionina, 2012). The main peculiarity of youth slang is the continual emotionality, expressiveness, evaluation and figurativeness of youth speech, which
384

brings along the overall dynamics of the Russian literary language.

\section{Results}

Our study is concerned with the use of English youth jargon by Russian young people, the peculiarity of rendering English to Russian slang, its factors, the development of slang in Russia. In the system of modern Russian and English languages jargon is very important. The study shows that jargon is not a literary language, it is characterized by a more emotional coloring, it falls into two groups: general and often used. Many slang expressions are incomprehensible to the population.

The study of word origins enjoyed considerable popularity in the past, and etymologies, a traditional component of a dictionary entry, were often hotly debated, even though 'the amateurs who, as late as 1900 , filled the pages of popular journals with their conjectures on word origins, had no idea that they should have used their time reading rather than writing' (Liberman, 2009).

In most cases, the adaptation process is long and gradual. Some elements remain not fully adapted. There 
may be some differences in pronunciation, they cannot be left out. If a borrowed word is adapted by the grammar system of the language, then it expands the possibilities of the formation of new derivatives. Thus, inanimate nouns with the subject and material lexical meanings can form various adjectives by means of Russian suffixes -ны (ым),- (ый): футбол-футбольный, хит-хитовый, some nouns form relative adjectives by means of the suffix: -ск (ий): президент - президентский, Уэльс-уэльский, nouns denoting various branches of science, art, social trends, etc., can form adjectives with the help of the suffixes: -ическом (ии): туризм - туристический .

Via the survey among young people, we have developed a conviction that they use jargon every day to designate specialties by the names of subjects, in interpersonal relations, in the sphere of life and leisure. The slang has been shaped and reshaped by different culture and the emergence of technology which become a phenomenon of the language development (Boase-Beier, 2004). Jargon is crucial in the life of youth, today their life is unthinkable without slang, which not only helps young people to communicate with each other, but also facilitates the process of learning new foreign vocabulary, expanding vocabulary.

We used questionnaires to identify the features of the use of anglicisms in the speech of students of Kazan Federal University, the results of which were the material for this study. The questionnaire consisted of the following questions:

1. Do you use the words of youth slang in communication with peers?

2. Why do you use slang expressions?

3. What words of youth slang do you use every day?

4. What television programs do you watch?

5.Give examples of English youth slang.

The students of the second course took part in the survey, all together thirty students.

\section{Discussion}

We have obtained the following results: all the students surveyed believe that youth jargon is an integral part of communication between peers. Such 
words allow them to maintain relationships with partners, communicate. The use of youth slang in a speech showed: $80 \%$ of the surveyed participants answered to the question "Do you use the words of youth slang in communicating with peers?" affirmatively that they used it for ease of communication with colleagues. Students answered that they mainly borrowed slang expressions from various television programs. Watching various television programs for youth, taking part in various sports events, online games are the reason for the frequent use of youth slang among peers. Many of the students use anglicisms the university among their coursemates. However, most students responded that they used these words everywhere $(58 \%), 71 \%$ of the surveyed students answered that they sometimes used borrowings in speech. Many young people $(80 \%)$ indicated that they understood the meaning of the anglicisms they used; more than half of students (40\%) used slang expressions because of momentum. Most students $(63 \%)$ are sure that slang has adversely affect our spoken language, but $37 \%$ of respondents are sure that the use of
386

borrowings helps to enrich our vocabulary.

\section{Summary}

At the moment, the influence of English on Russian, and especially on youth slang, is very widespread. Slang is jargon words or expressions in spoken language being characteristic of people of certain professions, for example, sailors, artists, etc (Bulyko, 2008).

From the English language we received a lot of words related to various fields of activity: politics, economics, sports, etc. As it turned out, borrowing often refers to different groups of education. However, at the present stage, schoolchildren are often not able to empathize, they are inclined to pragmatic reading, to receive information, and only during the analysis of a fictional work can they understand the depth of the text's intention and experience certain emotions (Kayumova et al., 2018). The data obtained during the study confirm the assumption about the widespread use of Englishisms. Youth slang in most cases is an English loan word or phonetic association. The reasons for the increase in slang expressions in the speech of modern adolescents are:

1. social factors; 
2. the importance of

communication with peers;

\section{References}

3. the influence of media Erofeeva, A. A., \& Yusupova, Z. F. (reading newspapers and youth magazines, watching TV programs), Internet resources. Effective communication, in its turn, is impossible without certain language skills (Kuzmina, et al., E. K., Nazarova, G. I., \& Nizamieva, L. R, (2018).

\section{Conclusion}

Youth slang is heavily (2018). Actual problems of teaching russian language as the language of the specialty of foreign students. Revista Publicando, 5(16 (1)), 324-331.

Arnold, I. V. (2010). Stylistics of Modern English: (Stylistics of Decoding): Textbook. Manual for Students of Pedagogical Institutes for Speciality "Foreign Language". - 3d edition - M.: Prosveshcheniye, 300 p. influenced by the English language. The peculiarities of the use of borrowing in the spoken language of adolescents identified during the study, unfortunately, are usually negative. The reason for this result is that Russian vocabulary is replaced by English loan words. In any case, we will not be able to stop the process of borrowing and spreading foreign words until we begin to create something unique.

\section{Acknowledgements}

The work is performed according to the Russian Government Program of Competitive Growth of Kazan Federal University.

Dai, W., \& He, Z. (2002). A new concise course on linguistics for students of English. Shanghai. Shanghai Foreign Language Education Press.(23-25).

Kudryavtseva, L. A., \& Prikhodko, I. G. (2006). Dictionary of Youth Slang of the City of Kiev. 2300 words and phrases: manual. Edited by L. A. Kudryavtseva K.: T. Shevchenko Kiev National University, 198 p.

Gorshunov, Y. V. (2012). Types of Semantic Relations Between the Components of Blends (Based on English Material). SPb.: Leningrad, 410 p. 
Mishina, N., Javgildina, Z., Mishina, A., Gainetdin, D., \& Belomoyeva, O. (2018). Design Practice as a Method of Professional Orientation of Teenagers in the System of Supplementary Education. Journal of History Culture and Art Research, 7(4), 132-137.

Hoey, M. (2012). Lexical priming: A new theory of words and language. Routledge. 155.

Jones, F. (2009). Literary translation. Routledge Encyclopaedia of Translation Studies, London: Routledge, 152-157.

Ionina, A. A. (2012). Peculiarities of Modern Textual Thinking. The SMS Language. - M.: Norma, 194 p.

Liberman, A. (2009). Word origins... and how we know them: Etymology for everyone. OUP USA.

Boase-Beier, J. (2004). Saying what someone else meant: style, relevance and translation. International Journal of Applied Linguistics, 14(2), 276-287. Bulyko, A. N. (2008). Large Dictionary of Foreign Words. 35000 Words. - M.: Martin, 704 p.
Kayumova, G. F., Makarova, V. F., \& Galiullin, R. R., (2018). Moral education of high school students in national (TurkiC) schools through literature. International Journal of Mechanical Engineering and Technology, 9(10), 1467-1475.

Kuzmina, E. K., Nazarova, G. I., \& Nizamieva, L. R, (2018). Innovative technologies of teaching business French. International Journal of Engineering and Technology(UAE), $7(4), 85-87$ 